\title{
PERSEPSI SISWA TERHADAP PENERAPAN SISTEM FULL DAY SCHOOL di MTS MARDHATILLAH SINGARAJA TAHUN AJARAN 2017/2018
}

\author{
Aulia Rahmah¹, lyus Akhmad Haris² \\ Jurusan Pendidikan Ekonomi \\ Universitas Pendidikan Ganesha \\ Singaraja, Indonesia
}

e-mail: al.shasaky@gmail.com¹, akhmad.haris@undiksha.ac.id²

\begin{abstract}
Abstrak
Penelitian ini bertujuan untuk mengetahui persepsi siswa terhadap penerapan sistem full day school serta kendala dan upaya yang dilakukan oleh MTs Mardhatillah. Populasi dalam penelitian ini berjumlah 137 siswa. Sampel di tentukan sebanyak 102 siswa yang diambil dengan menggunakan teknik proportional random sampling. Data dikumpulkan dengan metode wawancara dan kuesioner, analisis data yang digunakan adalah analisis deskriftif. Hasil penelitian menunjukan bahwa persepsi siswa terhadap penerapan sistem full day school di MTs Mardhatillah Singaraja Tahun Ajaran 2017/2018 secara dominan menunjukan kategori setuju. Kendala yang dihadapi siswa terkadang merasa bosan dan kurang berkonsentrasi karena belajar seharian, siswa merasa terbebani dengan Pekerjaan Rumah (PR) yang diberikan oleh guru di akhir pembelajaran, guru harus lebih banyak mempersiapkan materi karena durasi pembelajaran yang lebih lama dan guru memiliki waktu sedikit untuk melakukan evaluasi belajar. Upaya yang dilakukan guru untuk mengurangi siswa jenuh dalam mengikuti pembelajaran guru memberikan selingan baik berupa game maupun kegiatan belajar diluar ruangan untuk mata pelajaran tertentu dan guru selalu berusaha menggunakan metode pembelajaran sehingga siswa merasa senang dalam belajar sehingga tercipta pembelajaran yang aktif dan menyenangkan.
\end{abstract}

Kata kunci : Full day school, Persepsi Siswa.

\begin{abstract}
The purpose of this study is to determine, the perception of student to the implementation of full day school, the obstacles and effort made of MTs Mardhatillah. The population in this study were 137 student, the sample was determined as many as 102 student people were taken using proportional random sampling. Data were collected by interview method and analyzed descriptively. The result showed that the perception of student to the implementation of full day school in MTs Mardhatillah Singaraja Academic year 2017/2018, predominantly indicates the agreed category.Obstacles encountered students sometimes feel pampered and less concentrated on learning all day, students feel burdened with Homework (PR) provided by the teacher at the end of the lesson, the teacher should prepare more material because the duration of learning is longer, and teachers have little time to do learning evaluation. Efforts by teachers to reduce saturated students in following the teacher's learning to provide a good interlude in the form of games and outdoor learning activities for certain subjects and teachers always try to use the method of learning so that students feel happy in learning so as to create an active and fun learning.
\end{abstract}

Keyword : Full day school, perception of student. 


\section{PENDAHULUAN}

Full day school merupakan sekolah yang fokus pada kualitas dan kuantitas proses pembelajaran, dan mengedepankan kualitas input siswanya dan program pendidikan yang seluruh aktivitas berada di sekolah (sekolah sepanjang hari dengan ciri integratedactivity dan integrated curriculum). Menurut Aep Saifuddin (dalam Seli, 2009) bahwa dengan full day school sekolah lebih bisa intensif dan optimal dalam memberikan pendidikan kepada anak, terutama dalam pembentukan karakter. Sistem pembelajaan full day school merupakan suatu kreasi dan inovasi pembelajaran untuk mewujudkan sekolah unggul, inovatif serta kreatif dengan sistem pembelajaran terpadu (Sismanto, 2010). Artiya seluruh program dan aktivitas siswa yang di sekolah, mulai dari belajar, bermain, makan dan kegiatan keagamaan semua menjadi satu dalam suatu sistem pembelajaran full day school. Pada hakikatnya sistem pembelajaran full day school tidak hanya mengupayakan dalam menambah waktu dan memperbanyak materi pelajaran melainkan untuk mengkondisikan anak agar memiliki kebiasaan belajar yang baik. Selain itu agar dapat memasukkan materi-materi ke agamaan kedalam bidang studi, agar bisa dikuasai oleh anak-anak untuk bekal hidupnya. Intinya dari sistem pembelajaran full day school adalah bisa memberikan keseimbangan antara kebutuhan rohani dan jasmani, agar terbentuk kepribadian yang utuh (Yustanto, 2004: 150-151). Menurut Sismanto (2010) full day school merupakan model sekolah umum yang memadukan sistem pengajaran islam secara intensif yaitu dengan memberi tambahan waktu khusus untuk pendalaman keagamaan siswa. Biasanya jam tambahan tersebut dialokasikan pada jam setelah sholat dhuhur sampai sholat ashar, sehingga praktis sekolah model ini masuk pukul 07.00 WITA pulang pada pukul 16.00 WITA. Sedangkan pada sekolah-sekolah umum, anak-anak biasanya sekolah sampai pukul 13.00 WITA (Baharuddin,2010:227). Kegiatan full day school yang dilaksanakan di sekolah mulai pagi hari hingga sore hari, dalam kehidupan manusia karena dapat dijadikan pedoman dalam bertingkah laku. secara rutin sesuai dengan program pada tiap jenjang pendidikannya. Dalam full day school, lembaga bebas mengatur jadwal mata pelajaran sendiri dengan tetap mengacu pada standar nasional alokasi waktu sebagai standar minimal dan sesuai bobot mata pelajaran, ditambah dengan model-model pendalamannya (Baharuddin, 2010:221). Jadi yang terpenting dalam full day school adalah pengaturan jadwal mata pelajaran. Program ini banyak ditemukan pada sekolah tingkat dasar SD dan SMP swasta yang berstatus unggulan (Sulistiyaningsih, 2008:59). Dalam penerapannya sistem full day school membebaskan siswa untuk belajar dimana saja diarea sekolah, namun pada kenyataanya tidak semua siswa mampu mengikuti sistem full day school dengan baik karena, anak-anak cenderung kelelahan mengikuti pembelajaran. Berdasarkan Peraturan Menteri Pendidikan dan Kebudayaan Republik Indonesia Nomor 23 Tahun 2017 pada pasal 2 tentang hari sekolah ayat 1 hari sekolah dilaksanakan delapan jam dalam satu hari atau empat puluh jam selama lima hari dalam satu minggu, ayat 2 ketentuan delapan jam dalam satu hari atau empat puluh jam selama lima hari dalam satu Minggu sebagaimana dimaksud pada ayat 1 , termasuk waktu istirahat selama 0,5 jam dalam satu hari atau 2,5 jam selama lima hari dalam satu minggu, ayat 3 dalam hal diperlukan penambahan waktu istirahat sebagaimana dimaksud pada ayat 2 , sekolah dapat menambah waktu istirahat melebihi dari 0,5 jam dalam satu hari atau 2,5 jam selama lima hari dalam satu minggu, ayat 4 penambahan waktu istirahat sebagaimana dimaksud pada ayat 3 tidak termasuk dalam perhitungan jam sebagaimana dimaksud pada ayat 1 .

$$
\text { Menurut Sarwono (2007:94) }
$$

"persepsi adalah melibatkan alat indera dan proses kognisi yaitu menerima stimulus, mengorganisasikan stimulus serta menafsirkan stimulus dengan proses tersebut akan mempengaruhi prilaku dan sikap individu". Persepsi mempunyai peranan yang penting Kunci untuk memahami persepsi adalah terletak pada pengenalan bahwa persepsi 
itu merupakan suatu penafsiran yang unik terhadap situasi, dan bukannya pada suatu pencatatan yang benar terhadap sesuatu".Menurut Robbins (2002) terdapat tiga faktor yang mempengaruhi terbentuknya persepsi. Ketiga faktor tersebut adalah pelaku persepsi, objek yang dipersepsikan, konteks dari sitasi persepsi itu dilakukan. Pertama, pelaku persepsi (perceiver/orang yang membentuk persepsi itu sendiri). Ketika seorang individu melihat sebuah objek dan berusaha menginterpretasikan yang ia lihat, maka interpretasi tersebut pasti dipengaruhi oleh karakteristik pribadi dari perilaku persepsi. karakteristik pribadi dari pelaku yang mempengaruhi persepsi adalah sebagai berikut : Sikap merupakan reaksi atau respon individu terhadap stimulus atau objek. Sikap menggambarkan rasa suka atau tidak suka seseorang terhadap suatu objek. Sikap mempengaruhi persepsi individu terhadap objek tergantung pada individu sendiri untuk suka atau tidak suka terhadap objek, kebutuhan merupakan keinginan individu untuk menemukan jawaban yang sesuai dengan dirinya. Kebutuhan dapat mempengaruhi persepsi tergantung pada besar atau tidaknya keinginan individu mencari objek-objek atau pesan yang sesuai dengan keinginan dirinya, harapan adalah keinginan seseorang terhadap objek mengenai hal yang disukai dan diharapkan. Jadi harapan akan mempengaruhi persepsi individu terhadap objek jika objek tersebut disukai dan diharapkan. Kedua, objek yang dipersepsikan objek adalah objek yang dapat dipersepsi sangat banyak, yaitu segala sesuatu yang ada di lingkungan manusia. Dalam penelitian ini objek yang dipersepsi oleh siswa adalah penerapan full day school. Ketiga, konteks dari situasi persepsi itu dilakukan. Konteks dari situasi persepsi meliputi fasilitas dan suasana. Konteks dari situasi dapat mempengaruhi persepsi karena konteks situasi akan menyebabkan persepsi individu terhadap objek dapat berubah tergantung pada situasi, misalnya situasi proses belajar mengajar di area terbuka pada hari libur akan berbeda dengan situasi belajar mengajar di area lingkungan sekolah (kelas) pada hari efektif.
Dalam penerapan full day school terdapat siswa yang memiliki persepsi positif namun juga terdapat persepsi yang negatif. Persepsi positif merupakan penilaian individu terhadap suatu objek dan informasi sesuai dengan yang diharapkan dan dapat diterima secara rasional dan emosional. Sedangkan persepsi negatif merupakan pandangan individu terhadap objek atau informasi tertentu yang berlawanan dengan yang diharapkan dari objek yang dipersepsikan atau dari peraturan yang ada (Robbins, 2002). Dengan mengetahui persepsi siswa tentang penerapan sistem full day school dapat dicarikan solusi untuk mengatasi persepsi siswa yang beranggapan negatif tentang penerapan sistem full day school, agar penerapan sistem full day school berjalan dengan baik.

MTS Mardhatillah adalah salah lembaga pendidikan yang menerapkan sistem full day school. Lembaga ini dikelola oleh Yayasan Mardhatillah yang mencoba memadukan antara pengetahuan umum dan pengetahuan agama dalam kurikulumnya. Dalam penerapan full day school di MTS Mardhatillah dihadapkan oleh harapan siswa yang berbeda-beda. full day school untuk mengkondisikan anak agar memiliki kebiasaan belajar yang baik. Berdasarkan latar belakang di atas maka penelitian ini bertujuan untuk mencari "Persepsi Siswa terhadap Penerapan Sistem Full Day School di MTS Mardhatillah Singaraja Tahun Ajaran 2017/2018".

\section{METODE}

Penelitian ini dilakukan di MTs Mardhatillah Singaraja. Jenis data yang digunakan dalam penelitian ini adalah data kualitatif. Data kualitatif dalam penelitian ini yakni persepsi Siswa terhadap penerapan sistem full day school di MTS Mardhatillah Singaraja Tahun Ajaran 2017/2018. Sumber data yang digunakan dalam penelitian ini adalah data primer dan data sekunder. Data primer dalam penelitian ini yaitu hasil kuesioner yang diisi oleh siswa di MTs Madhatillah. Data sekunder berupa data yang diperoleh dari dokumen atau catatan pihak sekolah mengenai data jumlah siswa di MTs Madhatillah tahun ajaran 2017/2018. Instrumen penelitian ini 
berupa kuisioner dan wawancara, kuisioner untuk memperoleh data mengenai persepsi persepsi siswa terhadap penerapan sistem full day school di MTS Mardhatillah Singaraja Tahun Ajaran 2017/2018. Variabel akan diukur dengan model pendekatan skala likert. Wawancara menggunakan langkah-langkah seperti yang dikemukakan oleh Burhan Bungin (2003:70), yaitu pengumpulan data (data collection), reduksi data (data reduction), display data, verifikasi dan penegasan Kesimpulan (conclution drawing and verification). Dalam melakukan penelitian, peneliti menggunakan metode kuesioner. Kuesioner digunakan untuk memperoleh data tentang persepsi siswa terhadap penerapan sistem full day school di MTS Mardhatillah Singaraja Tahun Ajaran 2017/2018. Dalam penelitian ini kuesioner dibagikan kepada 102 siswa yang dijadikan sampel penelitian dari populasi yang

berjumlah 137 siswa.

Teknik pengambilan sampel menggunakan teknik proportional random sampling. Sedangkan kuesioner mengguanakan skala likert yang terdiri dari 5 (lima) pilihan jawaban kepada responden, yaitu pertama Sangat Tidak Setuju (STS), kedua Tidak Setuju (TS), ketiga Cukup Setuju (CS), keempat Setuju (S), dan kelima Sangat Setuju (SS). Teknik analisis data yang digunakan dalam penelitian ini adalah analisi deskriptif. analisis deskriptif digunakan untuk mendeskripsikan persepsi siswa terhadap penerapan sistem full day school di MTS Mardhatillah Singaraja Tahun Ajaran 2017/2018. Menurut Irianto (2004), untuk memperoleh skala interval persepsi dilakukan langkah-langkah sebagai berikut.

Pertama menentukan skor terendah dan skor tertinggi dari keseluruhan alternatif jawaban.

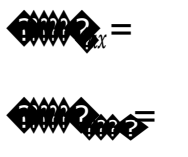

Nilai maksimal $x$ jumlah pertanyaan $x$ jumlah responden

Nilai manimal $\mathrm{x}$ jumlah pertanyaan $\mathrm{x}$ jumlah responden

Kedua menentukan interval persepsi Siswa terhadap penerapan sistem full day school di MTS Mardhatillah Singaraja Tahun Ajaran $2017 / 2018$

Interval =

Dari langkah-langkah yang telah dijelaskan di atas maka menghasilkan kriteria persepsi sebagai berikut. Kriteria skor persepsi siswa terhadap penerapan sistem full day school di MTs Mardhatillah dimensi pelaku persepsi yang terdiri dari tiga indikator yaitu indikator sikap, indikator harapan, dan indikator motivasi dapat dilihat pada tabel 1-3 dan kritera total dimensi pelaku persepsi dapat dilihat pada tabel

Tabel 1. Kriteria Skor Variabel Persepsi Siswa Terhadap Penerapan Sistem Full Day School di MTs Mardhatillah dari Indikator Sikap

\begin{tabular}{ll}
\hline Rentang skor & Kategori \\
\hline $3.836-4.590$ & Sangat setuju \\
$3.081-3.835$ & Setuju \\
$2.327-3.080$ & Cukup \\
$1.573-2.326$ & Kurang \\
$819-1.572$ & Sangat tidak setuju \\
\hline
\end{tabular}


Tabel 2. Kriteria Skor Variabel Persepsi Siswa Terhadap Penerapan Sistem Full Day School di MTs Mardhatillah dari Indikator Harapan

\begin{tabular}{ll}
\hline Rentang skor & Kategori \\
\hline $856-1.020$ & Sangat setuju \\
$693-855$ & Setuju \\
$530-692$ & Cukup \\
$366-529$ & Kurang \\
$202-365$ & Sangat tidak setuju \\
\hline
\end{tabular}

Tabel 3. Kriteria Skor Variabel Persepsi Siswa Terhadap Penerapan Sistem Full Day School di MTs Mardhatillah dari Indikator Motivasi

\begin{tabular}{ll}
\hline Rentang skor & Kategori \\
\hline $1.285-1.530$ & Sangat setuju \\
$1.039-1.284$ & Setuju \\
$793-1.038$ & Cukup \\
$547-792$ & Kurang \\
$301-546$ & Sangat tidak setuju \\
\hline
\end{tabular}

Tabel 4. Kriteria Total Skor Variabel Persepsi Siswa Terhadap Penerapan Sistem Full Day school di MTs Mardhatillah dari Dimensi Pelaku Persepsi

\begin{tabular}{ll}
\hline Rentang skor & Kategori \\
\hline $4712-5610$ & Sangat setuju \\
$3813-4711$ & Setuju \\
$2914-3812$ & Cukup \\
$2015-2913$ & Kurang \\
$1116-2014$ & Sangat tidak setuju \\
persepsi siswa terhadap & dipersepsikan dengan indikator penerapan \\
full day school di MTs & sistem full day school dapat dilihat pada \\
mensi objek yang & tabel 5 berikut
\end{tabular}

Tabel 5. Kriteria Skor Variabel Persepsi Siswa Terhadap Penerapan Sistem Full Day School di MTs Mardhatillah dari Indikator Penerapan Sistem Full Day School

\begin{tabular}{ll}
\hline Rentang skor & Kategori \\
\hline $1.285-1.530$ & Sangat setuju \\
$1.039-1.284$ & Setuju \\
$793-1.038$ & Cukup \\
$547-792$ & Kurang \\
$301-546$ & Sangat tidak setuju \\
\hline
\end{tabular}

Kriteria skor persepsi siswa terhadap penerapan sistem full day school di MTs dan indikator suasana dapat dilihat pada tabel 6-7 dan kritera total dimensi konteks Mardhatillah dimensi konteks dari situasi dari situasi dimana persepsi itu dilakukan dimana persepsi itu dilakukan yang terdiri dapat dilihat pada tabel 8 berikut ini. 
Tabel 6. Kriteria Skor Variabel Persepsi Siswa Terhadap Penerapan Sistem Full Day School di MTs Mardhatillah dari Indikator Fasilitas

\begin{tabular}{ll}
\hline Rentang skor & Kategori \\
\hline $2.142-2.550$ & Sangat setuju \\
$1.733-2.141$ & Setuju \\
$1.324-1.732$ & Cukup \\
$915-1.323$ & Kurang \\
$506-914$ & Sangat tidak setuju \\
\hline
\end{tabular}

Tabel 7. Kriteria Skor Variabel Persepsi Siswa Terhadap Penerapan Sistem Full Day School di MTs Mardhatillah dari Indikator Suasana

\begin{tabular}{ll}
\hline Rentang skor & Kategori \\
\hline $856-1.020$ & Sangat setuju \\
$693-855$ & Setuju \\
$530-692$ & Cukup \\
$366-529$ & Kurang \\
$202-365$ & Sangat tidak setuju \\
\hline
\end{tabular}

Tabel 8. Kriteria Total Skor Variabel Persepsi Siswa Terhadap Penerapan Sistem Full Day School di MTs Mardhatillah dari Dimensi Konteks dari Situasi dimana Persepsi itu dilakukan

\begin{tabular}{ll}
\hline Rentang skor & Kategori \\
\hline $2999-3570$ & Sangat setuju \\
$2427-2998$ & Setuju \\
$1855-2426$ & Cukup \\
$1283-1854$ & Kurang \\
$711-1282$ & Sangat tidak setuju \\
\hline
\end{tabular}

\section{HASIL DAN PEMBAHASAN}

Hasil

Berdasarkan perhitungan yang dilakukan dengan perbandingan skala interval yang diperoleh, maka dapat diketahui tingkat persepsi siswa terhadap penerapan sistem Full day school di MTs Mardhatillah ditinjau dari dimensi pelaku persepsi dapat dilihat pada tabel 9.

Tabel 9. Hasil Analisis Data Persepsi Siswa Terhadap Penerapan Sistem Full Day School di MTs Mardhatillah ditinjau dari Dimensi Pelaku Persepsi

\begin{tabular}{cccc}
\hline Indikator & Skor & Skala Interval & Kategori \\
\hline Sikap & 3.294 & $3.081-3.835$ & Setuju \\
Harapan & 929 & $856-1.020$ & Sangat Setuju \\
Motivasi & 1.292 & $1.285-1.530$ & Sangat Setuju \\
Skor Total & 5.515 & $4712-5610$ & Sangat Setuju \\
\hline
\end{tabular}

Hasil penelitian menunjukkan bahwa dimensi pelaku persepsi dengan indikator sikap diperoleh skor sebesar 3.294 sesuai dengan hasil perhitungan skala interval persepsi berada pada skala interval 3.081 -
3.835 sehingga persepsi dikatakan setuju, indikator harapan diperoleh skor sebesar 929 sesuai dengan hasil perhitungan skala interval persepsi berada pada skala interval 856 - 1.020 sehingga persepsi dikatakan 
sangat setuju, indikator motivasi diperoleh skor sebesar 1.292 sesuai dengan hasil perhitungan skala interval persepsi berada pada skala interval 1.285 - 1.530 sehingga persepsi dikatakan sangat setuju. Skor total dimensi pelaku persepsi diperoleh skor sebesar 5.515 sesuai dengan hasil perhitungan skala interval persepsi berada pada skala interval 4712 - 5610 sehingga persepsi dikatakan sangat setuju. Hal ini berarti siswa sangat setuju bahwa adanya partisipasi siswa dan mendukung terhadap penerapan sistem Full day school di MTs Mardhatillah. Siswa berharap penerapan sistem Full day school dipertahankan, serta mereka berharap guru bisa lebih kreatif lagi dalam menyampaikan materi, dan fasilitas bisa ditingkatkan lagi sehingga meningkatkan prestasi siswa.

Hasil analisis data persepsi siswa terhadap penerapan sistem full day school di MTs Mardhatillah ditinjau dari dimensi objek yang dipersepsikan dapat dilihat pada tabel 10.

Tabel 10. Hasil Analisis Data Persepsi Siswa Terhadap Penerapan Sistem Full Day School di MTs Mardhatillah ditinjau dari Dimensi Objek yang dipersepsikan

\begin{tabular}{cccc}
\hline Indikator & Skor & Skala Interval & Kategori \\
\hline $\begin{array}{c}\text { Penerapan sistem } \\
\text { Full day school } \\
\text { Skor Total }\end{array}$ & 1.209 & $1.039-1.284$ & Setuju \\
& 1.209 & $1.039-1.284$ & Setuju \\
\hline
\end{tabular}

Hasil penelitian menunjukkan bahwa dimensi objek yang dipersepsikan dengan indikator penerapan sistem Full day school diperoleh skor sebesar 1.209 sesuai dengan hasil perhitungan skala interval persepsi berada pada skala interval 1.039 1.284 sehingga persepsi dikatakan setuju. Hal ini menunjukan berarti penerapan sistem full day school berjalan dengan baik walaupun ada kendala yang dihadapi selama penerapan sistem full day school di MTs Mardhatillah Singaraja.

Hasil analisis data persepsi siswa terhadap penerapan sistem full day school di MTs Mardhatillah ditinjau dari dimensi Konteks dari situasi dimana persepsi itu dilakukan dapat dilihat pada tabel

Tabel 11. Hasil Analisis Data Persepsi Siswa Terhadap Penerapan Sistem Full Day School di MTs Mardhatillah ditinjau dari Dimensi Konteks dari Situasi dimana Persepsi itu dilakukan.

\begin{tabular}{cccc}
\hline Indikator & Skor & Skala Interval & Kategori \\
\hline Fasilitas & 2.140 & $2.142-2.550$ & Sangat Setuju \\
Suasana & 846 & $693-855$ & Setuju \\
Skor Total & 2.986 & $2427-2998$ & Setuju
\end{tabular}

Hasil penelitian menunjukkan bahwa persepsi siswa ditinjau dari dimensi konteks dari situasi dimana persepsi itu dilakukan yang mencakup fasilitas dan suasana dikategorikan setuju. Fasilitas yang disediakan oleh pihak sekolah untuk menunjang penerapan sistem full day school cukup membantu siswa untuk mengatasi kejenuhan selama berada disekolah seharian serta suasana lingkungan MTs Mardhatillah sangat nyaman dan kondusif karena, posisi sekolah berada deket persawahan.

Persepsi Siswa terhadap penerapan sistem Full day school di MTs Mardhatillah dimensi konteks dari situasi dimana persepsi itu dilakukan. Hasil presentase persepsi siswa terhadap penerapan sistem full day school di MTs Mardhatillah dapat dilihat pada tabel 12 . 
Tabel 12. Persentase Persepsi Siswa Terhadap Penerpan Sistem Full Day School di MTs Mardhatillah Singaraja

\begin{tabular}{|c|c|c|c|c|c|c|}
\hline \multirow[t]{2}{*}{ Dimensi } & \multirow[t]{2}{*}{ Indikator } & \multicolumn{5}{|c|}{ Persentase } \\
\hline & & SS & $\mathrm{S}$ & $\mathrm{KS}$ & TS & STS \\
\hline Pelaku Persepsi & Sikap & $14,8 \%$ & $61,8 \%$ & $11,8 \%$ & $1,2 \%$ & 0 \\
\hline & Harapan & $57,3 \%$ & $41,1 \%$ & $1 \%$ & $0,5 \%$ & 0 \\
\hline & Motivasi & $34,7 \%$ & $55,6 \%$ & $7,9 \%$ & $1,3 \%$ & $0,65 \%$ \\
\hline Total & & $35,6 \%$ & $52,8 \%$ & $15,4 \%$ & $2,6 \%$ & $0,22 \%$ \\
\hline $\begin{array}{l}\text { Objek yang di } \\
\text { persepsikan }\end{array}$ & $\begin{array}{l}\text { Penerapan sistem Full day } \\
\text { school }\end{array}$ & $17,6 \%$ & $63,1 \%$ & $16 \%$ & $3,2 \%$ & 0 \\
\hline Total & & $17,6 \%$ & $63,1 \%$ & $16 \%$ & $3,2 \%$ & 0 \\
\hline Konteks & Fasilitas & $23,9 \%$ & $52,8 \%$ & $5,9 \%$ & $8,2 \%$ & 0 \\
\hline & Suasana & $28 \%$ & $60,3 \%$ & $10,3 \%$ & $1,5 \%$ & 0 \\
\hline Total & & $25,9 \%$ & $56,6 \%$ & $8,1 \%$ & $4,9 \%$ & 0 \\
\hline
\end{tabular}

\section{Pembahasan}

Berdasarkan hasil penelitian, persepsi siswa terhadap penerapan sistem full day school di MTs Mardhatillah adalah semua menjawab setuju. siswa di MTs Mardhatillah mendukung, terbuka dan berpartispasi dengan adanya program full day school ini. Hal ini dapat dilihat dari hasil penelitian yang diperoleh dari tiga dimensi yaitu pelaku persepsi, objek yang dipersepsikan, dan konteks dari situasi dimana persepsi itu dilakukan. Jawaban responden terhadap masing-masing indikator berbeda. Hal ini sesuai dengan pendapat Robbins (2002) yang menyatakan bahwa meskipun setiap individu memiliki pandangan yang sama terhadap suatu objek, mereka akan mempersepsikannya berbeda-beda. Hasil penelitian menunjukkan bahwa persepsi siswa terhadap penerapan sistem full day scool dimensi pelaku persepsi yang mencakup indikator sikap sebesar 3.294 berada pada skala interval $3.081-3.835$ yang menunjukkan bahwa persespsi di kategorikan setuju. Hal ini berarti siswa setuju dengan penerapan sistem full day school mereka akan dapat banyak manfaat berada di sekolah dengan melaksanakan aktifitas-aktifitas belajar, siswa menunjukannya dengan rasa senang dan gembira berada di sekolah walaupun seharian penuh. Sikap yang ditunjukan yakni menunjukan tingkah laku positif seperti selalu mengikuti kegiatan yang telah dibuat oleh sekolah, aktif dalam kelas, suka pergi keperpustakaan, senang berlamalama sharing dengan guru. Indikator harapan sebesar 929 berada pada skala interval 856 - 1.020 yang menunjukkan bahwa persespsi di kategorikan sangat setuju. Hal ini menunjukan bahwa siswa berharap agar pelaksanaan full day school dapat membantu siswa berinteraksi dengan agar sekolah secara efektif dan juga siswa berharap dengan adanya full day school prestasi belajar siswa meningkat. Indikator motivasi sebesar 1.292 berada pada skala interval $1.285-1.530$ yang menunjukkan bahwa persespsi di kategorikan sangat setuju. Hal ini berarti siswa memiliki motivasi yang tinggi untuk dapat mengikuti penerapan sistem full day school agar nantinya dapat meningkatkan perkembangan ilmu pengetahuan umum, ilmu pengetahuan agama, teknologi, dan siswa juga beranggapan bahwa dengan adanya sistem full day school ini akan dapat meningkatkan nilai di semua mata pelajaran.

Sedangkan hasil penelitian menunjukkan bahwa persepsi siswa terhadap penerapan sistem full day scool dimensi objek yang dipersepsikan dengan indikator penerapan sistem full day school sebesar 1.209 berada pada skala interval 1.039 - 1.284 yang menunjukkan bahwa persespsi di kategorikan setuju. Hal ini berarti penerapan sistem full day school 
berjalan dengan baik walaupun ada kendala yang dihadapi selama penerapan sistem full day school di MTs Mardhatillah Singaraja. Sedangkan hasil penelitian menunjukkan bahwa persepsi siswa terhadap penerapan sistem full day school dari dimensi konteks dari situasi dimana persepsi itu dilakukan yang mencakup indikator fasilitas sebesar 2.140 berada pada skala interval $2.142-2.550$ yang menunjukkan bahwa persespsi di kategorikan sangat setuju. Hal ini menunjukan bahwa siswa merasa senang berada di sekolah karena, siswa tidak hanya menghabiskan waktu dikelas akan tetapi siswa bisa menghabiskan waktu di perpustakaan, di labotarium, ataupun menghabiskan waktu bermain basket dan sepakbola dilapangan sekolah. lindikator suasana sebesar 846 berada pada skala interval 693 - 855 yang menunjukkan bahwa persespsi di kategorikan setuju. Hal ini menunjukan bahwa siswa merasa tenang dan kondusif berada dikelas sehingga walaupun seharian berada disekolah proses belajar mengajar berjalan dengan baik. Sedangkan presentase dari tiga dimensi yakni pelaku persepsi jawaban responden Sangat Setuju (SS) 35,6\%, Setuju (S) 52,8\%, Kurang Setuju (KS) 15,4\%, Tidak Setuju (TS) 2,6\%, Sangat Tidak Setuju (STS) 0,22\%. Dimensi objek yang dipersepsikan jawaban responden Sangat Setuju (SS) 17,6\%, Setuju (S) $63,1 \%$, Kurang Setuju (KS) $16 \%$, Tidak Setuju (TS) 3,2\% Sangat Tidak Setuju (STS) $0 \%$. Dimensi konteks dari situasi dimana persepsi itu dilakukan jawaban responden Sangat Setuju (SS) 25,9\%, Setuju (S) 56,6\%, Kurang Setuju (KS) $8,1 \%$, Tidak Setuju (TS) 4,9\% Sangat Tidak Setuju (STS) 0\%.

Berdasarkan hasil wawancara yang telah diperoleh dari Kepala Sekolah dan guru terdapat beberapa kendala yang dihadapi oleh sekolah dalam penerapan sistem full day school di MTs Mardhatillah yaitu dari sisi siswa yakni siswa terkadang merasa bosan dan kurang berkonsentrasi karena belajar seharian. Selain itu siswa merasa terbebani dengan Pekerjaan Rumah (PR) yang diberikan oleh guru di akhir pembelajaran.dari sisi guru yakni guru harus lebih banyak mempersiapkan materi karena, durasi pembelajaran yang lebih lama. Selain itu guru memiliki waktu sedikit untuk melakukan evaluasi belajar. Sedangkan beberapa kendala yang dihadapi oleh sekolah dalam penerapan sistem full day school di MTs Mardhatillah maka adapun upaya yang dilakukan sebagai yaitu untuk mengurangi siswa jenuh dalam mengikuti pembelajaran yang menyenangkan sehingga siswa merasa senang dalam belajar sehingga guru memberikan selingan baik berupa game maupun kegiatan belajar diluar ruangan untuk mata pelajaran tertentu, guru selalu berusaha menggunakan metode pembelajaran menyenangkan tercipta pembelajaran yang aktif dan menyenangkan.

\section{SIMPULAN DAN SARAN Simpulan}

Hasil penelitian menunjukan bahwa persepsi siswa terhadap penerapan sistem full day school Mardhatillah di MTs Mardhaillah Singaraja Tahun Ajaran 2017/2018 dilihat dari tiga dimensi yakni pelaku persepsi sebesar 5.515 berada pada skala interval $4712-5610$ yang menunjukkan sangat setuju, dimensi objek yang dipersepsikan dengan indikator penerapan sistem full day school sebesar 1.209 berada pada skala interval 1.039 1.284 yang menunjukkan kategori setuju, imensi konteks dari situasi dimana persepsi itu dilakukan sebesar 2.986 berada pada skala interval $2427 \quad-2998$ yang menunjukkan kategori setuju.

Kendala yang dihadapi dalam penerapan sistem full day school dari sisi siswa yaitu siswa terkadang merasa bosan dan kurang berkonsentrasi karena belajar seharian, siswa merasa terbebani dengan Pekerjaan Rumah (PR) yang diberikan oleh guru di akhir pembelajaran, dari sisi guru yaitu guru harus lebih banyak mempersiapkan materi karena, durasi pembelajaran yang lebih lama dan guru semakin memiliki waktu lebih sedikit untuk melakukan evaluasi belajar.

Upaya yang dilakukan pihak sekolah untuk mengatasi kendala-kendala dalam penerapan sistem full day school di MTs Mardhatillah dari sisi siswa dengan guru memberikan selingan baik berupa game 
maupun kegiatan belajar diluar ruangan untuk mata pelajaran tertentu untuk mengurangi siswa jenuh dalam mengikuti pembelajaran dan guru selalu berusaha menggunakan metode pembelajaran yang menyenangkan sehingga siswa merasa senang dalam belajar sehingga tercipta pembelajaran yang aktif dan menyenangkan, dari sisi guru semua guru diberikan waktu khusus untuk melakukan sharing agar guru lebih kreatif menggunakan metode dalam pembelajaran.

\section{Saran}

Berdasarkan simpulan diatas, maka dapat dikemukakan beberapa saran yaitu. Bagi MTs Mardhatillah diharapkan kepada pihak sekolah agar lebih memperhatikan dan meningkatkan pengelolaan dalam penerapan sistem full day school agar seluruh warga sekolah terutama siswa merasakan manfaat dan tercapainya tujuan yang ingin dicapai. Bagi Akademik bagi peneliti lain ingin melakukan penelitian tentang full day school diharapkan mampu menganalisis dan membandingkan sistem full day school dengan penelitian lainnya untuk memperoleh solusi yang terbaik dalam penerapan sistem full day school di Bali ataupun di daerah lainnya. Selain itu, penelitian perlu dikembangkan dengan refrensi lainnya agar penelitian selanjutnya tentang full day school dapat berjalan dengan baik.

\section{DAFTAR PUSTAKA}

Baharuddin. 2010. Pendidikan dan Psikologi Perkembangan. Yogyakarta: Ar-Ruzz Media

Bungin, Burhan. 2003. Analisis Data Penelitian Kualitatif, Pemahaman Filosofi dan Metodologis ke Arah Pengusaan Model Aplikasi. Jakarta: PT.Raja Grafindo Persada

Irianto, Agus. 2004.Statistik Konsep Dasar dan Aplikasinya. Jakarta: Prenada Media

Peraturan Menteri Pendidikan dan kebudayaan Republik Indonesia Nomor 23 Tahun 2017
Robbins SP, \& Judge. 2002. Perilaku Oganisasi. Jakarta: Salemba Empat

Sarwono, S. 2007. Sosiologi Kesehatan Beberapa Konsep Beserta Aplikasinya. Malang: Hikmah Pustaka

Seli, Muhammad. 2009. Metode Pembelajaran Pendidikan Agama Islam dalam Full Day School di Sekolah Alam Bilingual Madrasah Tsanawiyah Surya Buana Lowokwaru Malang. Skripsi. Malang: Universitas Muhammadiyah Malang

Sismanto. 2010. Smart parenting, melejitkan karakter anak islam. Malang: Hikmah Pustaka

Sulistiyaningsih, Wiwik. 2008. Full day School dan Optimalisasi Perkembangan Anak. Yogyakarta: Paradigma Indonesia

Yustanto. 2004. Menggagas Pendidikan Islami Masa Depan. Jakarta: Balai Pustaka. 